\title{
Quality of Life at Work of Janitors Workers
}

\author{
Ma. Concepción Rodríguez-Nieto', Oswaldo Jiménez-Sánchez², José Armando Peña-Moreno³, Víctor Hugo \\ Ibarra-González ${ }^{4}$
}

Autonomous University of Nuevo León, México

lic_cony@yahoo.com¹,jimenez_js@hotmail.com², jose.penam@unal.mx³, hibarra01@gmail.com

\begin{abstract}
The aim of the study was to analyze the perception of quality of life in the work of janitor employees. The design was descriptive with a mixed approach. The 11 janitor workers of a Faculty of a public university participated and they responded individually to a questionnaire. In addition, eight of them participated in semi-structured interviews where the theme of study was addressed. The results showed that janitor workers have a high general perception of the quality of life at work associated with a high level of subjective wellbeing and satisfaction with work, good health and social interaction with coworkers, boss and members of the organization. For all janitor workers, the family is a great motivator and support in their daily lives and works. However, a work-family imbalance was found that women perceive greater than men.
\end{abstract}

Indexing terms/Keywords: quality of life at work, job satisfaction, subjective well-being, work-family balance.

Subject Classification: Library of Congress Classification

Type (Method/Approach): The study has a mixed methodology, uses survey and interviews

\section{Introduction}

At each stage of life, the person plays several roles that must be organized to achieve a balance that allows a satisfactory development and fulfillment that manifests itself in a well-being. A role that intervenes in multiple areas of personal, family, social and work life because it provides economic resources with which the person must meet their needs is the "worker" that is acquired by having a job, in other words a paid job . Work is one of the keys for personal development, for integration with groups of friends, for managing leisure and for the organization of life and home (De Miguel \& De Miguel, 2002).

The worker invests many hours of the day in a work space in which physical and social conditions converge to which he arrives with his particularities and personal aspirations that he must manage to achieve an efficient execution of his work and a balance between his work life and the external world. The quality of life at work is associated with objective characteristics of the work and the subjective evaluation that the person makes of them (Steffgen, Khol, Reese, Happ, \& Sischka, 2015). The emphasis of the meaning of the construct is the worker's assessment of his work life, in the subjective, individual psychological experience and satisfaction (Lehman, 1988) and, it is important because it can support or not to health, safety and a better balance between the employee's personal and work life (Eurofond, 2016a).

Having work is related to satisfaction with life (Kapitán, Kovaks \& Krieger, 2005) that symbolizes a summary or global assessment of it as a whole (Castro-Solano, 2010) and, is affected by the ability of people to successfully harmonize work with family life (Wallace, Pichler, \& Hayes, 2007). The balance work-family is characterized by feeling that they have been able to satisfy multiple demands of the domains of work and family (Greenhaus \& Beutell, 1985). This balance is important to improve the quality of life in general and for the family to be sustainable in the face of the pressures faced by workers in today's world (Wallace et al., 2007).

In recent decades, the importance of quality of life at work has been recognized for its influence on physical and mental health, job satisfaction, well-being and work-family balance of the employee and multiple investigations 
(eg Beham \& Drobonic, 2010; Bobé, Trobat, Sampietro, 2008; Dahl, Nesheim \& Olsen, 2009; Eurofond, 2016a and b; Eurfond, 2017; Greenhaus, Collin, \& Shaw, 2003; Steffgen et al., 2015; Wallace et al., 2007). However, specific studies on janitor employees are scarce in the international context and in Mexico they almost do not exist. Therefore, the purpose of this study was to analyze the quality of life at work in janitor workers.

\section{Literature review}

The concept of quality of life at work was used for the first time in the General Motors organization where it was necessary to evaluate employee satisfaction in order to develop programs that increase productivity (Goode, 1989). The quality of life at work is based on the opinions, attitudes, expectations and interpretation of the workers on all the conditions of their work and satisfaction of their needs (Sirgy, Efraty, Siegel, \& Lee, 2001) so it is directly associated with the worker's health and well-being (Steffgen et al., 2015).

There are indicators of the quality of life at work. Some of the most important are social support (Bakker, \& Demerouti, 2007; Beham \& Drobonic, 2010; Drobnic, 2016), job security and salary (Clark, 2001, Dahl, Nesheim \& Olsen, 2009). A well-paid job is associated with greater satisfaction at work and with life (Drobnic, 2016). Social support can provide emotional support, help to complete a task on time and to work efficiently because it reduces work overload (Bakker, \& Demerouti, 2007). In addition, social support as well as the control that people feel about important things in their lives is positively related to mental health (Pearlin, 1999) and satisfaction with work-family balance (Beham \& Drobonic, 2010). When there is a positive social climate at work, $89 \%$ of workers report working satisfactorily with their colleagues (Eurofond, 2016b) and when in the work environment there are poor social relations the risk of depression, anxiety and cardiovascular diseases increases (Hansen et al. al., 2006). Nowadays, some of the negative aspects of the work are the increase in time pressure and the difficulties to reconcile paid work and private life (Drobnic, 2011, Taylor-Gooby 2004).

\section{Quality of life at work and well-being}

Quality of life at work is strongly associated with the quality of life (Sashkin \& Burke, 1987). Employees consider work as a resource for personal growth and social support (Karce \& Booth-Kewley, 1993) so that the quality of life at work becomes a part of the quality of life of the person (Martel \& Dupuis, 2006). Quality of life depends on culture and refers to the general well-being of people because it incorporates the balance between work and personal life, health and subjective well-being, among other aspects (Eurfond, 2017).

Subjective well-being is a global judgment of the person's overall life (Diener, Sandvik, Seidlitz \& Diener, 1993) that depends on beliefs and represents the overall effectiveness of an individual's psychological functioning in life inside and outside of work (Wright \& Cropanzano, 2000). Fisher and Hanna (1931) found that 90\% of employee turnover and $50 \%$ of absenteeism were due to difficulties associated with well-being. When workers report high job satisfaction and well-being, their job performance is high (Wright, Russell, \& Bonett, 2007) and, when welfare is low, there is a negative association with job satisfaction (Cropanzano \& Wright, 2001; Wright \& Bonett, 2007). Workers who perceive a high level of well-being are more creative, resilient, socially related and physically and mentally healthy than those with a low level of well-being (Wright 2005).

The subjective well-being has indicators such as autonomy, having time to enjoy life and satisfaction with life, (Eurofound, 2017). Satisfaction is a psychological state resulting from the difference between the situation in which a person finds himself and the situation in which that person wishes to be (Quilty et al., 2003). Satisfaction in a domain of life can influence the satisfaction of another domain (Sirgy et al., 2001). For example, job satisfaction can affect areas such as financial, family, social, leisure, health, etc. (Gropel \& Kuhl, 2009).

People with employment perceive much higher levels of life satisfaction than those who do not. In the United States, an important predictor of satisfaction with life is having a good job (Haller \& Hadler, 2006) and the factor that most affects this satisfaction is having or not having a job (Frey \& Stutzer, 2005). It is often assumed that a good job leads to satisfaction, which is not necessarily true. Various investigations have shown the "Paradox of Satisfaction" where women and men with few skills with jobs of low qualifications and well paid are satisfied 
with their employment (Hakim, 2000). This Paradox is explained in men by salary, in women by family life and because both groups find external factors that compensate for the low quality of work.

Job satisfaction is job specific, excludes other aspects of external life (Wright \& Bonett, 2007) and is a predictor of life satisfaction, general well-being (Danna \& Griffin, 1999) and effective work performance (Judge, Thoresen, Bono \& Patton, 2001; Wright et al., 2007). Satisfied employees are motivated to work harder and offer better services (Gropel \& Kuhl, 2009). In the Survey of Quality of Life at Work of the Ministry of Labor and Immigration of Spain in 2007, it was reported that in Catalonia overall satisfaction at work was 7.3 and satisfaction with the work activity developed of 7.7 out of a maximum average of 10 (Bobé, et al., 2008).

Unfavorable work conditions reduce job satisfaction, affecting the physical and mental health of employees and increase turnover intentions (Cropanzano, Rupp, \& Byrne, 2003). The work environment in the service sector produces emotional exhaustion, stress and low levels of job satisfaction that is reflected in a high rate of attrition (Hillmer, Hillmer, \& McRoberts, 2004). Fahey Nolan and Whelan (2003) argue that a work environment that facilitates a balanced situation between work and family is crucial for the quality of life.

\section{Work-family balance}

The importance of the work-family balance is based on the idea that people with a favorable balance between these factors will have higher levels of quality of life at work and satisfaction with life than those with a poor balance in these aspects (Wallace et al., 2007).

Work and family life are interdependent, they are not separate worlds (Greenhaus \& Beutell, 1985) although in each of these dimensions people have different roles. The work-family balance is an evaluation of the individual of his working life, it is the degree to which he can satisfy his/her important needs through his/her experiences in the organization (Kiriago \& Bwisa, 2013). The balance is determined by the feeling of having achieved a satisfactory resolution of the demands of both dimensions (Greenhaus \& Beutell, 1985) and is essential to ensure that work is sustainable for all (Eurofond, 2018).

Work-family experiences influence physical and mental health (Bianchi \& Milkie, 2010). There is evidence that some people are able to combine work and family life satisfactorily while others, when trying, report high levels of stress (Strandh \& Nordenmark, 2003). Greenhaus et al., (2003) found that professionals employed in public accounting who spent more time with family than at work perceived a better quality of life than people who spent the same amount of time on work and family, who in turn experienced a better quality of life than those who spent more time working than family.

In the Sixth European Quality of Life Survey (EQLS) of 2016, problems related to work-life balance are measured with three questions: being too tired from work to do domestic work, experiencing difficulties in fulfilling family responsibilities for time what happens at work and having difficulty concentrating on work for family responsibilities (Eurofond, 2017)). 81\% of European workers declare a good or very good harmony between their work and their family or social commitments. The number of workers who claim to perceive problems in the work-life balance at least several times a month had a significant increase, especially between 2011 and 2016 in all measured dimensions (Eurofond, 2017).

The difficulties in balancing work and family life associated with the greater participation of women in employment are one of the main challenges of the current century (Taylor-Gooby, 2004). The Sixth European Survey on Working Conditions (EWCS) reports that women continue to take care of most of the unpaid work at home (Eurofond, 2016b) and that they experience more fatigue from work than men. Two thirds of women under the age of 34 are too tired from work to do housework at least several times a month. Two thirds of women under 34 are too tired from work to do domestic work at least several times a month and $41 \%$ have difficulty fulfilling family responsibilities for time spent at work. In 2016, 61\% of men aged 35-49 reported being too tired to carry out housework after work and $42 \%$ had difficulty fulfilling family responsibilities for time at 
work (Eurofound, 2017). Although, the time spent at work has a negative impact on family tasks, there is no significant difference between men and women (Eurofound, 2017).

Families are changing with the structure of the workforce. This change implies that parents adapt to new roles within and outside the family (Podder \& Poder, 2015). Although men help a little more in household activities, women continue to take care of most unpaid work in the home (Eurofond, 2016). Caring for children continues to be much more the responsibility of mothers than of fathers and paid work hours continue to be greater for fathers than for mothers (Bianchi \& Milkie, 2010). Mothers perform a greater variety of tasks, spend more time alone with children and have more overall responsibility for caring for their children than parents (Craigh, 2006). Likewise, mothers' leisure is of lower quality than that of their parents because it is combined with other tasks, including childcare (Mattingly \& Bianchi, 2003). The aspect of greatest difficulty in the imbalance between work and family life is the double burden of women (Hoem, 2000) because people have difficulties in adopting new roles (Hobson, 2002).

The gender perspective argues that definitions of masculinity incorporate the role of the economic provider and that men resist doing tasks defined as feminine, especially when their performance as a provider is compromised (Bittman, England, Sayer, Folbre \& Matheson, 2003). Therefore, the role of the provider remains important for men (Christiansen \& Palkovitz, 2001). The study of the well-being state is through domestic equality and the distribution of domestic work / paid work (Podder \& Poder, 2015) and in the present intra-family inequalities are a great obstacle to a work-family balance (Esping-Andersen $\&$ Myles, 2007).

\section{Materials and Methods}

This study is part of a broader investigation about the quality of life at work and this article presents only the results of the indicators of well-being, job satisfaction, personal satisfaction, working conditions and work-family balance.

\section{Design}

The study is descriptive with a mixed approach because quantitative and qualitative data were integrated for a better understanding of the information collected.

\section{Participants}

The total number of janitor workers (11) from a Faculty of a Public University of Mexico. Eight women and three men. The age range was 39 to 62 years (average 46.9 years), with a seniority in the position from 2 to 37 years (average 17 years). Five workers with a plant contract and six with a temporary contract.

\section{Materials}

First Survey of Quality of Life at Work of the European Foundation for the Improvement of Living and Working Conditions (Wallace et al., 2007). Nine questions are reported: two from the indicator of subjective well-being and the indicator of satisfaction at work, both on a scale of 1 to 10, two questions with five response options for indicators of working conditions, one related to the permanence in employment and another with stress at work and four questions with three options of response indicator work and life balance. Survey of Quality of Life at Work of the Ministry of Labor and Social Affairs of Spain of 1999. The data of seven questions are reported. Three questions the personal satisfaction indicator and two questions related to the family. All these questions have five response options.

In addition, semi-structured interviews were conducted with key questions about social interaction in the workplace, satisfaction at work, physical health, family situation and use of free time. 
All questions of the questionnaires and the interview were reviewed, analyzed and validated by three expert judges in labor and organizational psychology.

\section{Procedure}

The permission for the realization of this study was requested and obtained from the authorities of the Institution and that it was during the working hours of the cleaning employees. Subsequently, each worker was informed of the purpose of the investigation, of the informed consent where the anonymity and the confidentiality of the information provided were emphasized and their voluntary participation was requested. After the workers accepted and signed the informed consent, the work schedules were revised to locate the times of less activity or rest and to agree on a suitable agenda for the application of instruments.

The questionnaires were applied individually. When a worker finished answering the questionnaires, he was invited to participate in an interview to deepen aspects of the quality of life at work. Seven workers agreed to be interviewed individually.

A database with quantitative information was generated and descriptive statistics were used. The responses of the interviews were analyzed by two coders through a process of reading and rereading to identify key aspects reported in the specialized literature and emerging issues. All the extracts of a specific category were read, analyzed and compared again to corroborate or reconsider the assignment to a category or emerging theme.

The reliability of the questions of the semi-structured interview was the product of the degree of overlap or pairing and interpretation of the most outstanding characteristics of the categorization made in the content analysis and the contrast of results with premises and theoretical constructs of the specialized literature. The validity lies in the intersubjective verification between the two independent coders who worked on identifying the categories of analysis and emerging issues through a reading and rereading process to compare both descriptions and discuss them to minimize overlaps until sufficient evidence and evidence is gathered to guarantee the veracity of the results.

Subsequently, similarities and differences were identified with theoretical proposals and previous investigations, percentages were obtained from the detected categories, quantitative and qualitative results were integrated and inferences related to the study topic were made.

\section{Results}

The perception of quality of life in the work of janitor workers is high (Table 1).

Table 1 General perception of the quality of life at work

\begin{tabular}{ccc}
\hline All participants & Women & Men \\
\hline & Mean* \\
\hline 4.3 & 4.4 & 4.2 \\
\hline
\end{tabular}

* Maximum Mean: 5

The workers reported high subjective well-being and job satisfaction (Table 2). 
Table 2 Perception of subjective well-being and satisfaction with work

\begin{tabular}{lcc}
\hline \multicolumn{1}{c}{ Participants } & Subjective well-being & Satisfaction with work \\
\hline & Mean* & \\
\hline All & 9.8 & 9.9 \\
Women & 9.6 & 9.7 \\
Men & 10 & 10 \\
\hline
\end{tabular}

* Maximum Mean: 10

$81 \%$ of the janitor workers perceive their job as insurance and think that they could hardly or very hard lose it. In addition, employees consider that their salary is adequate and a level of work stress higher than the average that is higher in men than in women (Table 3).

Table 3 Salary and work stress

\begin{tabular}{ccc}
\hline Participants & Adequate salary & Work stress \\
\hline All & Mean* $^{*}$ & \\
Women & 3.2 & 2.9 \\
Men & 3.3 & 3.7 \\
\hline
\end{tabular}

The interviews were characterized by short and specific responses from the janitor workers. The eight participants reported being satisfied with their work for reasons such as schedules that allow them to be with their children, security in the workplace, facilities for permits, benefits and vacations, etc. However, the most satisfactory for cleaning employees are social relations with teachers and students (43\%), recognition of their work, external motivation to excel and autonomy in the performance of their duties (29\%).

In the labor context, the climate of social interaction is positive. $86 \%$ of workers report good relationships with their boss and $71 \%$ with colleagues. In the physical health dimension, $100 \%$ of the participants reported having a good night's sleep, $81 \%$ did not have medical permits in the last six months and the same percentage reported not getting sick frequently.

The family is of great importance for janitor workers (Table 4).

Table 4 Perception of the family

\begin{tabular}{lc}
\hline \multicolumn{1}{c}{ Indicator } & Mean \\
\hline I have a good family relationship & 4.7 \\
My family supports me in what I do & 4.8 \\
\hline
\end{tabular}




\begin{tabular}{lc}
\hline My partner serves as motivation & 4.8 \\
I feel satisfied with my family & 4.9 \\
My family is the most important for me & 4.9 \\
\hline
\end{tabular}

* Maximum Mean: 5

The interviews showed that all the workers live with the spouse or partner, $86 \%$ have children living with them, $86 \%$ of the wives also work, $100 \%$ of mothers with children of an age school only attends school by grades and $71 \%$ of men report that they collaborate in the work of the home.

Women report a lower work-family balance than men (Table 5).

Table 5 Time for activities related to work-family balance

\begin{tabular}{lccc}
\hline \multicolumn{1}{c}{ Participants } & All & Women & Men \\
\cline { 2 - 4 } Enough time & & $\% 6$ & 100 \\
\hline To do the job & 81 & 43 & 67 \\
To share with the family & 45 & 43 & 100 \\
To help in the works of the house & 54 & 14 & 86 \\
To go out with friends & 36 & & \\
\hline
\end{tabular}

\section{Discussion}

In the janitor workers, the general perception of quality of life at work, subjective well-being and job satisfaction were at a very high positive level and were reflected in their indicators of social support, job security and health. These associations have also been found in previous research (eg Bakker, \& Demerouti, 2007, Beham \& Drobonic, 2010, Drobnic, 2016, Clark, 2001, Dahl et al., 2009, Eurofond, 2016a, Steffgen et al., 2015). Employees perceive a satisfactory social work climate maintained by social support that is revealed in good relations with bosses and colleagues, with teachers and students who recognize the importance of their work and are a source of external motivation to overcome. Most workers perceive that it is difficult or very difficult for them to lose their jobs and they would like their salary to be a little higher.

Satisfaction with work in men was total and in women slightly lower. The high job satisfaction of the cleaning workers is related to the Paradox of Satisfaction (Hakim, 2000) because although the work is of low qualification they are satisfied with their employment, the salary is adequate and the working hours allow to attend at least partially to the family. In this case, the job satisfaction in addition to working hours that allow being with the children were: security in the workplace, facilities for permits, benefits and vacations, etc., and social support in the workplace. These results are consistent with the report of the Survey of Quality of Life in the Work of the Ministry of Labor and Immigration of Spain of 2007 that indicates a high level of global satisfaction with work and with the labor activity carried out by workers (Bobé et al. al., 2008).

Work stress was higher than the average, and higher in men than in women. However, in the janitor workers these levels of stress have little impact on their physical health because most of them do not get sick frequently, have not had medical permits in the last six months and reported sleeping well. An explanation of the diffuse effect of stress is that the high perception of quality of life at work and job satisfaction has a protective role that counteracts the adverse consequences that these levels of stress could cause. 
In the employees of the cleaning the subjective well-being was very high and when integrating it with the high labor satisfaction it bases the high quality of life in the work and allows to infer that the objective and subjective contextual working conditions that circumscribe the position that they perform are adequate and that meet their needs (Sirgy et al., 2001). The positive relationship between job satisfaction and subjective well-being was previously reported by Cropanzano and Wright (2001) and Wright, Russell and Bonett (2007). In this study, the association between a high level of well-being, physical and mental health and appropriate social relationships (Danna Griffin, 1999, Wright 2005) was manifested when workers in addition to high subjective well-being reported having good health and perceiving a social work climate satisfactory.

The family is one of the axes of life of the Mexican. The janitor workers declared that the family is the most important thing for them, that they are very satisfied with their families, so it is a significant source of support and motivation. Sirgey et al. (2001) argue that satisfaction in one domain of life can influence the satisfaction of another domain. Cleaning workers perceive that they have a high quality of life at work, high job satisfaction, good health, high satisfaction with the family and a high subjective well-being that is the overall assessment of their lives (Diener et al., 1993) so it is inferred that these areas of life are closely related and influence each other.

All workers live with their spouse or partner who also has a job and they have children of different ages who almost always live with them even if they are married. This composition of the families showed that women have a greater workload than men because of the responsibility assumed for unpaid work in the home and for a job. Men are perceived more as providers of economic resources than as responsible in the work of the home.

Janitor employees have difficulty balancing their work and family life. The work-family imbalance was observed in the perception of the investment of sufficient time to carry out work activities related to the family, housework and friends. Almost all men and women believe that the time that the time to perform their work tasks is sufficient, but that the time available to be with the family is much smaller and even more reduced for coexistence with friends.

The comparison by gender indicates differences in the perception of time to perform activities at home. All men believe that it is enough and less than half of women think the same. This disparity is an indicator that although men collaborate in household tasks, women continue to take care of most of this work (Eurofond, 2016).

The most marked discrepancy between genders is in the perception of time to go out with friends since most men consider that it is enough and almost no woman thinks that this is the case. Going out with friends is a leisure activity that in general terms has a lower quality in mothers than in parents, in them it is combined with other tasks such as childcare (Mattingly \& Bianchi, 2003).

In this study, women only attend their children's school to collect grades, which implies that attention to their children's academic training is limited and none of the participants reported having their partner support them in this function, so that man's participation in it is supposed to be reduced. This result is consistent with previous studies that found that the general responsibility and care of the children is still much more in charge of the mothers than of the parents (Craigh, 2006). Men should further modify their role as an economic provider to support more in housework and childcare than is traditionally done. The transformation of the man's role is happening, since most of the cleaning workers reported collaborating in the housework.

\section{Conclusions}

Cleaning workers perceive a high quality of life at work and job satisfaction associated with a satisfactory social work environment expressed in social support, autonomy in the performance of their duties and safety in their job.

The workers reported a slightly high level of stress and an imbalance between work-family. They also perceive a high quality of life at work, high job satisfaction, a high level of subjective well-being and the family as an axis 
of life, motivator and support that can be protective factors that probably allow them to properly face adverse components of $\mathrm{n}$ the everyday life and work such as stress and work-family imbalance.

The lack of balance in the work-family balance is much more accentuated in women than in men, particularly in the distribution of household chores and the care of children that continues to be a responsibility mainly of women although men collaborate in these activities.

\section{Conflicts of Interest}

The authors express that we do not present conflicts of interest to the editor of this manuscript.

\section{Funding Statement}

The study has been self-financed.

\section{References}

1. Bakker, A. B. \& Demerouti, E. (2007). The job demands-resources model: State of the art. Journal of Managerial Psychology, 22(3), 309-328. DOI: 10.1108/02683940710733115.

2. Beham, B. \& Drobonic, S. (2010). Satisfaction with work-life balance among German office workers. Journal of Managerial Psychology, 25(6), 669-689. DOI: 10.1108/02683941011056987.

3. Bianchi, S. M. \& Milkie, M. A. (2010). Work and Family Research in the First Decade of the 21st Century. Journal of Marriage and Family, 72, 705-725. DOI: 10.1111/j.1741-3737.2010.00726.

4. Bittman, M., England, P., Sayer, L. C., Folbre, N., \& Matheson, G. (2003). When does gender trump money? Bargaining and time in household work. American Journal of Sociology, 109, 186-214.

5. Bobé, N., Trobat, M. \& Sampietro, M. C. (2008). Encuesta de Calidad de vida en el trabajo. Departament de Treball, Institut d'Estadística de Catalunya. Santander, España.

6. Castro-Solano, A. (2010). Fundamentos de Psicología Positiva. Buenos Aires: Paidós

7. Clark, A. E. (2001). What really matters in a job? Hedonic measurement using quit data. Labour Econnomics, 8, 223-242.

8. Cropanzano, R. \& Wright, T. A. (2001). When a "happy" worker is a "productive" worker: A review and further refinement of the happy-productive worker thesis. Consulting Psychology Journal: Practice and Research, 53, 182-199.

9. Cropanzano, R., Rupp, D. E., \& Byrne, Z. S. (2003). The relationship of emotional exhaustion to work attitudes, job performance, and organizational citizenship behaviours. Journal of Applied Psychology, 88(1), 160-169.

10. Craig, L. (2006). Does father care mean fathers share? A comparison of how mothers and fathers in intact families spend time with children. Gender \& Society, 20, 259-281.

11. Christiansen, S. L. \& Palkovitz, R. (2001). Why the "good provider" role still matters: Providing as a form of paternal involvement. Journal of Family Issues, 22, 84-106.

12. Dahl, S. A. Nesheim, T. \& Olsen, K. M. (2009). Quality of Work-Concept and Measurement. REC-WP 05/2009; RECWOWE Publication, Dissemination and Dialogue Centre: Edinburgh, Scotland, UK, 2009. 
http://www.socialpolicy.ed.ac.uk/

_data/assets/pdf_file/0020/29720/REC-

WP_0509_DahI_Nesheim_Olsen.pdf.

13. Danna, K. \& Griffin, R. W. (1999). Health and well-being in the workplace: A review and synthesis of the literature. Journal of Management, 25, 357-384.

14. De Miguel, A. \& De Miguel, I. (2002). La Calidad de Vida laboral y organización del trabajo: informes y estudios. Madrid: Ministerio del Trabajo y Asuntos Sociales. Subdirección General de Publicaciones.

15. Diener, E., Sandvik, E., Seidlitz, L., \& Diener, M. (1993). The relationship between income and subjective wellbeing: Relative or absolute? Social Indicators Research, 28, 195-223.

16. Drobnic, S. (2011). Introduction: Job quality and work-life balance. In S. Drobnic, \& A. M. Guillén (Eds.), Work-life balance in Europe. The Role of job quality, pp. 1-14. Ed. Palgrave Macmillan, London UK.

17. Drobnic, S. (2016). Quality of (working) life and work-life balance. https://inclusivegrowth.be/downloads/calls/call-34-cee/day-3-sonja-drobnic-presentation.pdf

18. Esping-Andersen, G. \& Myles, J. (2007). The Welfare State and Redistribution https://www.researchgate.net/publication/255583959_The_Welfare_State_and_Redistribution.

19. Eurofond (2016a). Equilibrio entre trabajo y la vida personal: crear soluciones para todos. Foundation FOCUS. 19, 1-19.

20. Eurofond (2016b). Sexta encuesta europea sobre las condiciones de trabajo. Informe General: Resumen ejecutivo https://www.eurofound.europa.eu/es/publications/executive-summary/2016/workingconditions/sixth-european-working-conditions-survey-overview-report-executive-summary.

21. Eurofound (2017). European Quality of Life Survey 2016: Quality of life, quality of public services, and quality of society, publications Office of the European Union, Luxembourg.

22. Eurofond (2018). Equilibrio entre la vida privada y la vida laboral. 16 July 2018 https://www.eurofound.europa.eu/es/topic/work-life-balance

23. Frey, B. \& Stutzer, A. (2005). A happiness research: State and prospects. Review Social Economics, LXII, 207-228

24. Fahey, T., Nolan, B. \& Whelan, C. (2003). Monitoring quality of life in Europe. European Foundation for the Improvement of Living and Working Conditions. Luxemburg, Office for Official Publications of the European Communities. htt://www.eurofound.europa.eu/publications/htmlfiles/ef02108.htm.

25. Fisher, V. E., \& Hanna, J. V. (1931). The dissatisfied worker. New York: Macmillan.

26. Goode, D. A. (1989). Quality of life, quality of work life. In W. E. Kiernan \& R. L. Schalock (Eds.), Economics, Industry and Disability: A Look Ahead, pp. 337-349. Paul H. Brookes, Baltimore. USA.

27. Greenhaus, J. H. \& Beutell, N. J. (1985). Sources of conflict between work and family roles. Academy of Management Review, 10(1), 76-88.

28. Greenhaus, J. H., Collin, K. M., \& Shaw, D. (2003). The relation between work-family balance and quality of life. Journal of Vocational Behavior, 63(3), 510-531. DOI: 10.1016/S0001-8791 (02)00042-8.

29. Gropel, P. \& Kuhl, J. (2009). Work-Life Balance and Subjective Well-Being: The Mediating Role of Need Fulfillment. British Journal of Psychology, 100(2), 365-375. 
30. Hakim, C. (2000). Work-lifestyle Choices in the 21st century: Preference Theory. Oxford University.

31. Haller, M. \& Haller, M. (2006). How social relations and structures can produce happiness and unhappiness: An international comparative analysis. Social Indicators Research. 75, 169-216.

32. Hillmer, S., Hillmer, B. \& McRoberts, G. (2004). The real costs of turnover: Lessons from a call centre. Human Resource Planning, 27(3), 34-41.

33. Hansen, A. M., Hogh, A., Persson, R., Karlson, B., Garde, A. H. \& Orbaek, P. (2006). Bullying at work, health outcomes, and physiological stress response. Journal of Psychosomatic Research, 60, 63-72.

34. Hobson, B. (2002). Introduction: Making Men into Fathers. In B. Hobson (Ed.), Men, Masculinities and the Social Politics of Fatherhood. pp. 1-24. Cambridge: University Press.

35. Hoem, B. (2000). Entry into motherhood in Sweden: the influence of economic factors on the rise and fall in fertility, 1986-1997. Demographic Research, 2(4). DOI: 10.4054/DemRes.2000.2.4.

36. Judge, T. A., Thoresen, C. J., Bono, J. E., \& Patton, G. K. (2001). The job satisfaction-job performance relationship: A qualitative and quantitative review. Psychological Bulletin, 127, 376-407.

37. Kapitány, B., Kovaks, K. \& Krieger, H. (2005). European Foundation for the Improvement of Living and Working Conditions, Working and living in an enlarged Europe, Luxembourg, Office for Official Publications of the Curopean http://www.eurofound.europa.eu/publications/htmlfiles/ef0595.htm.

38. Kerce, E. W. \& S. Booth-Kewley (1993). Quality of work life surveys in organizations: Methods and benefits. In Sage Focus (Eds.), Improving Organizational Surveys: New Directions, Methods, and Applications, pp. 188-209. Sage Publications, Thousand Oaks, CA.

39. Kiriago, A. N. \& Bwisa, H. M. (2013). Working Environment Factors that Affect Quality of Work Life among Attendants in Petrol Stations in Kitale Town in Kenya International Journal of Academic Research in Business and Social Sciences, 3(5), 289-296.

40. Lehman, A. F. (1988). A quality of life interview for the chronically mental ill (QOLI). Evaluation and Program Planning, 11, 51-62.

41. Martel, J. M. \& Dupuis, G. (2006). Quality of work life: theoretical and methodological problems and presentation of a new model and measuring instrument. Social Indicators Research. DOI 10.1007/s11205-004-5368-4.

42. Mattingly, M. J., \& Bianchi, S. M. (2003). Gender differences in the quantity and quality of free time: The U.S. experience. Social Forces, 81, 999-1030.

43. Ministerio de Trabajo y Asuntos Sociales de España (1999). Encuesta de Calidad de Vida en el Trabajo. Madrid.

44. Pearlin, L. I. (1999). The stress process revisited: Reflections on concepts and their interrelationships. In C. S. Aneshensel \& J. C. Phelan (Eds.), Handbook of the sociology of mental health, pp. 395-415. New York: Plenum.

45. Podder, H. \& Poder, K. (2015). The societal context of significant others: comparative perceptions of mothers and fatherhood in Sweden, Finland and Estonia. European Scientific Journal, 11(11), 222-247. 
46. Quilty, L. C., Van Ameringen, M., Mancini, C., Oakman, J., \& Farvolden, P. (2003). Quality of life and anxiety disorders. Journal of Anxiety Disorders 17, 405-426.

47. Sashkin, M. \& W. W. Burke (1987). Organizational development in the 1980's. Journal of Management, 13(2), 393-417.

48. Sirgy, M., Efraty, D., Siegel, P. \& Lee, Dong-Jin (2001). A new measure of quality of working life (QWL) based on need satisfaction and spillover theories, Social Indicators Research, 55, 241-302.

49. Strand, M. \& Nordenmark, M. (2003). Do Family friendly policies influence the costs of feing flexible? The interference of paid work with family life in different social policy contexts. In Wallace, C. (Ed.). HWF Survey Comparative Report volume 2: Thematic Papers, Vienna Institute for Advanced Studies. HWF Project.

50. Steffgen, G., Khol, D., Reese, G., Happ, Ch., \& Sischka, P. (2015). Quality of Work: Validation of a new instrument in three languages. International Journal of Environment Research and Public Health, 12, 14988-15006. DOI: 10.3390/ijerph121214958.

51. Taylor-Gooby, P. (2004). New risks and social change. In Taylor-Gooby, P. (Ed.) New risks, new welfare: The transformation of the European welfare state, pp. 1-29. Oxford University Press, Oxford.

52. Wallace, C., Pichler, F., \& Hayes, B. C. (2007). First European quality of Life Survey: Quality of Work and life satisfaction. European Foundation for the Improvement of Living and Working Conditions. https://www.eurofound.europa.eu/sites/default/files/ef_publication/field_ef_document/ef0695en.pdf.

53. Wright, T. A. (2005). The role of "happiness" in organizational research: Past, present and future directions. In P. L. Perrewe \& D. C. Ganster (Eds.), Research in occupational stress and well-being, Vol. 4, pp. 225-268. Amsterdam: JAI Press.

54. Wright, T. A. \& Bonett, D. G. (2007). Job satisfaction and Psychological well-being as non-additive predictors of workplace turnover. Journal of Management, 33(2), 141-160. DOI: $10.1177 / 0149206306297582$.

55. Wright, T. A., Russell, C., \& Bonett, D. G. (2007). The Moderating Role of Employee Positive Well Being on the Relation between Job Satisfaction and Job Performance. Journal of Occupational Health Psychology, 12(2), 93-104. DOI: 10.1037/1076-8998.12.2.93. 